\title{
Urban poor families access to assets and implication on household's food security, the situation of low-income households in City of Kigali, Rwanda
}

\author{
Emmanuel NZEYIMANA (PhD Candidate), Prof. Maurice M. SAKWA, PhD, Prof. Gregory NAMUSONGE.
}

\author{
Jomo Kenyatta University of Agriculture and Technology, Development Studies
}

DOI: $10.29322 /$ IJSRP.10.02.2020.p9802

http://dx.doi.org/10.29322/IJSRP.10.02.2020.p9802

\begin{abstract}
In 2015, poorer households owning fewer assets and with more unstable sources of income were more likely to have experienced food shortages and shocks (NISR, 2015) and Bashir et al. (2012) state that households with ownership to land and livestock to be associated with less food insecurity levels.

This paper aimed to analyze how access to assets, access to finance and level of education for the head of household in lowincome households in City of Kigali influence household's level of food security. Our research has focused on how the three key factors; i) Household owned assets (Land, shelter), ii) Employment/occupation status of the head of the household (Employed: full time, part time, casual labor, Unemployed, doing skilled labor or non-skilled labor) and iii) Household access to financial services (loans), influence livelihoods for the lowincome households in City of Kigali.

The research has revealed that majority of low income HHs, $76.7 \%$ do not have access to assets like land an houses, $5 \%$ have confirmed to own houses while $8 \%$ own land, majority (89.7\%) of the heads of low-income households earns daily wages and only $10.3 \%$ earn monthly salaries. Only $29.5 \%$ of the heads of households have confirmed that their salaries/wages are regular while $70.5 \%$ said that it they are irregular.
\end{abstract}

The results from the Multiple Linear Regression Model has revealed that there is no statistical significant relationship between the three variables with the low-income household's food security in City of Kigali, meaning that food security for the income families in City of Kigali does not depend with the formal employment of the head of household, access to finance from formal Financial Service Providers, nor it does not depend on household owned assets (land and house).

Index Terms- Urban poor families, access to assets, food security and low-income household.

\section{INTRODUCTION}

$\mathrm{U}$ rban poor families generally rely on purchased foods, mainly coming from rural areas or imported into the country, however, due to lack of means mainly financial resources, many of the urban poor have less alternatives for them to have food for their family members. In Cities, mostly poor families who are migrant from rural areas they don't own assets like land and houses which could help them to either do some farming activities or earn some income for them to be able to easily access food for their families.

The recent financial/economic crisis and the rising food, fuel and energy prices have affected the poor in both rural and urban areas, although having a disproportionately large effect on the urban poor. The latter are particularly vulnerable to changes in food prices and variation in income, since food makes up a large part of their household expenses (H. DE Zeeuw et al, 2010).

Government of Rwanda has developed a number of policies and programs to support job creation and the development of the private sector. However, it has failed to recognize the important role that household enterprises can and do play in creating nonfarm employment as a distinct sector of the labor market, and one that needs to have policies and programs specifically tailored to meet its needs. Reducing the risk and increasing the productivity of household enterprises will be important not only in creating jobs and but also in reducing poverty (Abbott et al 2010; Abbott and Rwirahira 2010).

Household enterprise concept should work well and be the best solution for the low-income households in City of Kigali, who have few of their family members who are educated to be eligible to rely on employments and salaries in the formal sector, Joachim (1993) reiterated that there is a high likelihood that employment will switch from the formal to the informal labor market and that income flows will become more unstable, Maintaining or achieving food security for such low-income urban households therefore is crucial. The same families own very few assets (Land or Houses) and this make them city dwellers, also these families have a very limited access to financial services including loans which aggravate their incapacity to afford food stuff purchased from the market.

The 2012 FinScope report findings indicated that 1.4 million (56\%) of the 2.3 million Rwandan adults istepiwho are currently not formally served are not very likely to offer new opportunities for formal financial inclusion in the short or medium term. SEP Poverty is a significant barrier for these individuals. Almost $50 \%$ of them are from households isepin the two lowest categories of the Ubudehe socio-economic classification system; $65 \%$ of them had often run out of cash and had to make a plan for their daily needs in the 6 month period before the FinScope 2012 survey (AFR, 2012)

Access to financial services has been identified as a major constraint on the development of the private-sector generally and a barrier preventing poor people moving out of poverty (World 
Bank 2007) as well as the main constraint on the start-up and growth of household enterprises (Abbott et al 2010; Gaal 2010). While access to finance has been developed as a key strategy for reducing poverty and providing the poor with opportunities to start and grow enterprises in Rwanda, not all household enterprises operators are ready for or need micro-finance. It is evident that many are not credit worthy and would have difficulty in repaying loans or might even default were they to be given finance (IPAR, 2010).

This paper will shade clarity on the relationship between the low-income households economic characteristics with focus on three factors; i) Employment for the head of household, ii) Household Access to assets (Land \& house) and iii) Household access to finance and their food security in the City of Kigali.

\section{LITERATURE REVIEW}

The ability of households to avoid or reduce vulnerability and to increase economic productivity depends on their initial assets and on their ability to transform those assets into income, food or other basic necessities, by intensifying existing, developing new, or diversifying their strategies (Rakodi, 2002). This was reiterated on by Lanjouw and Stern (1991) in their different surveys in $1957 / 58$ and in $1983 / 84$, which revealed that landless and widow-headed households are more likely to experience poverty. Sharma (1999) stated that incidence of poverty is also high in households with no land for subsistence production. Moreover, households that have no land ownership have limited access to credits.

The phenomenon of urbanization, which will be one of the strongest social forces in the coming years, brings severe challenges to ensuring household food security in a context characterized by high rates of unemployment, increasing development of the informal sector, deteriorating infrastructure, overcrowding and environmental degradation. One major challenge will be how to provide adequate quantities of nutritious and affordable food for more urban inhabitants, with less water, land and labor (FAO, 2008).

Maxwell (1999) suggested several reasons for the invisibility of urban food security, all of which still apply. First, at the city level, urban food insecurity is obscured by more urgent urban problems such as unemployment, the burgeoning of the informal sector, overcrowding, decaying infrastructure, and declining services. Secondly, national policymakers tend to equate food insecurity with rural areas, where it is a more visible seasonal and community-wide phenomenon. Thirdly, urban food insecurity is usually dealt with at the household or individual level: "so long as food insecurity is a household-level problem and does not translate into a political problem, it does not attract policy attention." (Crush, J et al, 2010).

Several researches have shown that access to credit has a positive impact on household economic welfare (Khandker, 1998; Panjaitan, Drioadisuryo and Kathleen, 1999; Remenyi and Benjamin, 2000; Wright, 2000; Khandker and Faraque, 2001; Coleman, 2002). Also, literatures show that most microfinance programs do not serve the poorest, but when they do so, the poorest can benefit from microfinance through increased income and reduced vulnerability (Morduch and Haley, 2002). The research will study the reliance level of low-income household's food security on their accessibility to financial services specially loans and the uptake of the low-income households for the informal services through elf-help groups such as Village Saving and Loans Associations (VSLAs) versus financial services accessed through formal financial service providers such as Banks, MFIs and SACCOs.

\section{RESEARCH METHODOLOGY}

This study was carried out to investigate how HH's economic characteristics influence households' food security for the low income households in City of Kigali, the survey was conducted in 3 districts of the City of Kigali namely; Nyarugenge, Gasabo and Kicukiro districts in their 35 Sectors which are distributed by 10 Sectors in Nyarugenge, 15 Sectors in Gasabo and 10 Sectors in Kicukiro.

This paper focuses on how HH's economic characteristics defined by three factors; i) Household owned assets (Land, shelter), ii) Employment/occupation status of the head of the household (Employed: full time, part time, casual labor, Unemployed, doing skilled labor or non-skilled labor) and iii) Household access to financial services (loans), influence livelihoods for the low-income households in City of Kigali.

The respondents (Heads of household) were selected using simple random sampling. Data on household food expenditure and HHs' perception on of food security using HFIAS were provided by household heads using a memory recall method. A total of four hundred and forty five copies of the questionnaires were administered but 407 were found useful for the analysis. The data gathered were analyzed using SPSS for descriptive statistics and a Multiple Linear Regression Model.

\section{Model specification: \\ $\boldsymbol{Y}_{\square}=\alpha+\sum_{0}^{n} \beta X i+\varepsilon$ \\ $\boldsymbol{Y}_{\square}=\beta 0+\beta 1 X 1+\beta 1 X 1+\ldots \ldots . \beta n X n$}

Where

- $\quad \boldsymbol{Y}_{\square}$ refers to Household Food Expenditure

- $\quad \boldsymbol{\alpha}$ is a constant term.

- $\quad \boldsymbol{\beta}$ : Refers to parameter estimates

- $\quad \boldsymbol{X}$ i: Refers to a latent of explanatory variables assumed to affect household food expenditure.

- $\quad \boldsymbol{\varepsilon}$ : Error term

Table 1: Description of Variables

\begin{tabular}{lcl}
\hline Variables & Description of variable \\
\hline HH_Food & - & HH food expenditure \\
Security & - & HH perception on Quality \& \\
& & Quantity of Food (Sufficiency \& \\
& & Affordability) \\
& - & Number of meals taken a day \\
\hline HH_Income & - & Wages \& salaries \\
& - & Remittances \\
& - & Income generating activities \\
\hline HH_Demo & - & Age of Head of HH \\
Charact & - & Dependency Ratio \\
& - & Gender of HH Head \\
\hline
\end{tabular}




\begin{tabular}{lll}
\hline HH_Econ & - & HH owned assets (Shelter and \\
Charact & & land) \\
& - & Employment status of HH head \\
& - & HH access to financial services \\
& (Loan) \\
\hline HH_Soc Charact & - & Household Size \\
& - & Social capital \\
& - & Education level of HH head \\
\hline
\end{tabular}

IV. RESULTS AND DISCUSSIONS

\subsection{Descriptive statistics}

Table 2: Respondents Demographic Characteristics

\begin{tabular}{|c|c|c|}
\hline I. Age range & Frequency & Percent \\
\hline 20-30 Years & 104 & 25.6 \\
\hline $31-40$ Years & 131 & 32.2 \\
\hline 41-50 Years & 78 & 19.2 \\
\hline 51-65 Years & 66 & 16.2 \\
\hline$>65$ Years & 28 & 6.9 \\
\hline Total & 407 & 100 \\
\hline \multicolumn{3}{|l|}{ II. Gender } \\
\hline Male & 186 & 45.7 \\
\hline Female & 221 & 54.3 \\
\hline Total & 407 & 100 \\
\hline \multicolumn{3}{|l|}{ I. Monthly income } \\
\hline$\overline{0-10,000 \text { Rwf }}$ & 112 & 27.5 \\
\hline $10,001-30,000$ Rwf & 145 & 35.6 \\
\hline 30,001-50,000 Rwf & 77 & 18.9 \\
\hline 50,001-80,000 Rwf & 42 & 10.3 \\
\hline 80,001-100,000 Rwf & 18 & 4.4 \\
\hline 100,001-150,000 Rwf & 9 & 2.2 \\
\hline$>150,000$ Rwf & 4 & 1 \\
\hline Total & 407 & 100 \\
\hline \multicolumn{3}{|l|}{ II. Received support } \\
\hline None & 366 & 89.9 \\
\hline 1-10,000 Rwf & 9 & 2.2 \\
\hline 10,001-20,000 Rwf & 15 & 3.7 \\
\hline $20,001-40,000$ Rwf & 11 & 2.7 \\
\hline $40,001-60,000 \mathrm{Rwf}$ & 6 & 1.5 \\
\hline Total & 407 & 100 \\
\hline \multicolumn{3}{|l|}{ IV. Owned Assets } \\
\hline House & 118 & 29.2 \\
\hline Land & 10 & 2.5 \\
\hline TV & 8 & 2 \\
\hline Sofa set & 34 & 8.4 \\
\hline Telephone & 90 & 22.3 \\
\hline Radio & 30 & 7.4 \\
\hline Bicycle & 10 & 2.5 \\
\hline Moto & 1 & 0.2 \\
\hline None & 97 & 23.3 \\
\hline Other & 10 & 2.5 \\
\hline Total & 407 & 100 \\
\hline \multicolumn{3}{|l|}{ V. Employment status } \\
\hline Unemployed & 254 & 62.4 \\
\hline Self employed & 70 & 17.2 \\
\hline By Government & 10 & 2.5 \\
\hline By the private sector & 71 & 17.4 \\
\hline By Civil society & 2 & 0.5 \\
\hline Total & 407 & 100 \\
\hline \multicolumn{3}{|l|}{ VI. Profession } \\
\hline Agriculture/Agribusiness & 62 & 15.2 \\
\hline Plumber & 2 & 0.5 \\
\hline Masson & 18 & 4.4 \\
\hline Carpenter & 1 & 0.25 \\
\hline Teacher & 1 & 0.25 \\
\hline Other & 72 & 17.7 \\
\hline None & 251 & 61.7 \\
\hline Total & 407 & 100 \\
\hline \multicolumn{3}{|l|}{ VII. Access to Finance } \\
\hline $\mathrm{SACCO}$ & 81 & 19.9 \\
\hline MFI & 7 & 1.7 \\
\hline Commercial banks & 26 & 6.4 \\
\hline None & 284 & 69.8 \\
\hline Others & 9 & 2.2 \\
\hline Total & 407 & 100 \\
\hline
\end{tabular}

Source: Author's field study, 2019

\subsubsection{Age}

The survey sought to study demographic characteristics of the Low Income Households in City of Kigali with focus on the households' heads; age, gender, marital status, gender ratio and dependency ratio at household level. The survey revealed that 
majority of the households $(93 \%)$, are headed by people in the working age range between 15 and 64 years old, and the age average for the heads of the low-income households in City of Kigali is around 41 years old (Table 2).

\subsubsection{Gender and Sex ratio}

The research has also revealed that $35 \%$ of the low-income HHs in City of Kigali counts between 2 to 3 females members while the household that has minimum of male has is 0 and household with maximum of males has 7 males. The sex ratio Male/Female is $99.1 \%$ as per the table 3 below, meaning that there are 99 males for every 100 females. NISR (2014) defines Sex ratio as an indicator that shows the balance between sexes within a given population in relation to a given time period. It is calculated as the number of males divided by the number of females, thus providing the number of males per 100 females within a given population.

Table 3: Ratio Statistics for total male / total female

\begin{tabular}{ccccc}
\hline Minimum & Maximum & $\begin{array}{c}\text { Price Related } \\
\text { Differential }\end{array}$ & $\begin{array}{c}\text { Coefficient of } \\
\text { Dispersion }\end{array}$ & $\begin{array}{c}\text { Coefficient of Variation } \\
\text { Median Centered }\end{array}$ \\
\hline .000 & 7.000 & 1.306 & .670 & $99.1 \%$ \\
\hline
\end{tabular}

Source: Author's field study, 2019

\subsubsection{Marital status}

The research also revealed that the majority of the lowincome households $68 \%$ are headed by married people and $\mathbf{1 5 \%}$ of the households are headed by widows while only $9 \%$ of households are headed by single people and $\mathbf{8 \%}$ headed by divorced people. The research has revealed also that the majority of low-income households in City of Kigali $71 \%$ count between 3 and 6 members and the average number of members is 4 members (Table 4).

Table 4: Marital statuses and Size of Households

\begin{tabular}{lcclcc}
\hline & Marital Status & \multicolumn{3}{c}{ Household Size } \\
\hline Status & Frequency & Percent & \# Of HH Members & Frequency & Percent \\
Single & 37 & 9.1 & $1-2$ Members & 60 & 14.7 \\
Married & 277 & 68.1 & $3-6$ Members & 289 & 71.0 \\
Divorced & 32 & 7.9 & $7-10$ Members & 49 & 12.0 \\
Widow & 61 & 15.0 & $>10$ Members & 9 & 2.2 \\
Total & $\mathbf{4 0 7}$ & $\mathbf{1 0 0 . 0}$ & Total & $\mathbf{4 0 7}$ & $\mathbf{1 0 0 . 0}$ \\
\hline
\end{tabular}

Source: Author's field study, 2019

\subsubsection{Salaries and wages}

The research revealed that the majority $82 \%$ of the low income-households in City of Kigali earns a monthly income between 10,000 and 50,000 Rwf, with an average income of 34,646 Rwf (Figure 4.4). The majority of the head of low incomehouseholds are involved in informal and non skilled types of labor; they mentioned street vendors and other informal businesses which occupy $4.9 \%$, those involved in man power category are $2.7 \%$, cleaners are $1.3 \%$, aid-masons are $1.3 \%$ and those involved in security employments are $1.1 \%$, the reason of the low earnings. The $63 \%$ of the low income HHs who earn between 10,000 and 30,000 Rwf they can spend up to $\mathbf{2 3 \%}$ of their earning \{ $\operatorname{Max} 7,000$ Rwf $\}$ on food. The second group of HHs that earn between 30,001 and 50,000 Rwf they seem to have tendency as they can spend up to $60 \%$ of their earning on food $\{$ Max 30,000 Rwf $\}$. Therefore, we can say that the low income HHs in City of Kigali spends between 23 to $60 \%$ of their income on food. This research has revealed that, the low-income households in City of Kigali spend on average $\mathbf{6 0 . 5 \%}$ of their income on food.

\subsubsection{Income Generating Activities (IGA)}

The research has reveled that a very small portion $23.1 \%$ of the low income households in City of Kigali are involved in income generating activities while the majority $76.9 \%$ do not have any income generating activities. Among the few who own income-generating activities; $4.4 \%$ are involved in agribusiness, $1.7 \%$ involved in small animals rearing and $17 \%$ in microenterprises (Table 5). 
Table 5: Income generating activities

\begin{tabular}{lcc}
\hline Income generating activities & Frequency & Percent \\
\hline Agriculture produces retailing & 18 & 4.4 \\
Animal rearing \{small ruminants & 7 & 1.7 \\
Micro-enterprise & 69 & 17.0 \\
None & 313 & 76.9 \\
\hline Total & 407 & 100.0 \\
\hline
\end{tabular}

Source: Author's field study, 2019

The above situation of only $17 \%$ of the poor families involved in income generating activities within the City of Kigali reveals certainly the absence of purchasing power for these families and uncertainty on their capacities to feed their family members. Small businesses and entrepreneurial spirit should be among sources of income for the poor families who depends on purchased food.

\subsubsection{Remittances}

According to National Institute of Statistics of Rwanda (NISR, 2015), the Government of Rwanda considers that social protection provides income support to poor households or those at risk of falling into poverty, as well as interventions to help them overcome financial barriers to accessing public services such as health care and education, and also provide associated in-kind assistance essential in contribution to the achievement of its development goals.
The Rwanda's main National Social Protection Programme is the Vision 2020 Umurenge Program (VUP), which began, in mid 2008, run by MINALOC. It contains three components: a regular cash transfer for very poor households with no labour capacity ('VUP Direct Support'), a public works programme for very poor households who are able to work ('VUP Public Works') and a microcredit scheme that provides small loans at low interest rates to individuals or groups ('VUP Financial Services'). Only households classified as ubudehe categories 1 and 2- the two poorest categories in the six-point ranking determined by local communities in their own neighborhood are eligible for Direct Support or Public Works.

The research has revealed that only $12.5 \%$ of the lowincome households in city of Kigali receives support under Government social protection programs. Among the surveyed households $4.9 \%$ receive "food support" while $7.6 \%$ receive "cash support" (Table 6).

Table 6: Access and Types of remittances in low income HHs

\begin{tabular}{lccccc}
\hline \multicolumn{2}{c}{ HH receiving remittances } & \multicolumn{3}{c}{ Types of Remittances } \\
\hline \multirow{3}{*}{ Fo } & Frequency & Percent & Type & Frequency & Percent \\
Yes & 356 & 87.5 & No & 356 & 87.5 \\
& 51 & 12.5 & Cash & 31 & 7.6 \\
& & & Food & 20 & 4.9 \\
\hline Total & 407 & 100 & Total & 407 & 100 \\
\hline
\end{tabular}

Source: Author's field study, 2019

Among those who confirmed that they receive food and cash support, $30 \%$ said that the provider is the Government, $30 \%$ they receive the supports from other providers, $25 \%$ they receive the support from friends while $15 \%$ they receive them from relatives. The low income HHs in City of Kigali who receives special support from Governments project like Vision 2020 Umurenge Project $\left(\mathrm{VUP}^{1}\right)$ and $\mathrm{Ubudehe}^{2}$ they spend between 40 and $60 \%$ of the support buying the food for their households.

The Vision 2020 Umurenge Project/VUP as most of its approach is "Cash for work" it the mostly found within some areas of the City because of projects; construction of infrastructures like roads etc... that are implemented within the City which give employment opportunities to members in poor families. 41

\footnotetext{
${ }^{1}$ VUP: Govt program targeting poor families \{Food and work $\}$.
}

households confirmed that they benefited from the VUP program and they have received from it on average the income of 26,707 Rwf (Figure 4.8) and only 7 households confirmed to benefits from Ubudehe Government support.

\subsubsection{Education Situation}

Education has been demonstrated to play a paramount role in both food access and utilization Sekhampu (2013) showed households with more educated and skilled members to have a higher likelihood of attaining resources and hence less food secure. Burchi \& De Muro (2016) argued that education improves the nutritional capabilities of households and hence indirectly important for household dietary qualities.

\footnotetext{
${ }^{2}$ Ubudehe: Govt program targeting to finance IGA for the poorest of the poor.
} 
The survey has revealed that majority of Heads of Households, $46.7 \%$ they have primary level of education, $13.5 \%$ have secondary level and $1.7 \%$ and $3.7 \%$ have TVET level; 5 and
3 years respectively. Only $6.2 \%$ have University levels, generally $24 \%$ are not educated at all.

Table 7: Education level for the Heads of HHs

\begin{tabular}{lcccccccc}
\hline & \multicolumn{2}{c}{ Primary } & \multicolumn{2}{c}{ Secondary } & \multicolumn{2}{c}{ TVETs } & \multicolumn{2}{c}{ University } \\
\hline Years & Frequency & Percent & Frequency & Percent & Frequency & Percent & Frequency & Percent \\
\hline 0 year & 87 & 24.0 & 225 & 74.0 & 240 & 81.6 & 267 & 92.1 \\
6 Months & 4 & 1.1 & 1 & .3 & 13 & 4.4 & - & - \\
1 Years & 6 & 1.7 & 1 & .3 & 15 & 5.1 & 1 & .3 \\
2 Years & 8 & 2.2 & 9 & 3.0 & 7 & 2.4 & 2 & .7 \\
3 Years & 26 & 7.2 & 19 & 6.3 & 11 & 3.7 & 2 & .7 \\
4 Years & 29 & 8.0 & 2 & .7 & 3 & 1.0 & 5 & 1.7 \\
5Years & 33 & 9.1 & 6 & 2.0 & 5 & 1.7 & 13 & 4.5 \\
6 Years & 169 & 46.7 & 41 & 13.5 & - & - & - & \\
\hline Total & 362 & 100.0 & 304 & 100.0 & 294 & 100.0 & 290 & 100.0 \\
\hline
\end{tabular}

Source: Author's field study, 2019

According to this research, majority (46.7\%) of the heads of low-income households in City of Kigali they have completed 6 years of Primary, $13.5 \%$ they have completed 6 years of Secondary Education, $1.7 \%$ they have completed 5 years of TVETs and only $4.5 \%$ they have completed University Education.

In terms of frequentation; $24 \%$ of the Heads of low-income households they have never been to school (0 year Primary), 74\% they have never attended Secondary education (0 year in Secondary) while, $92.1 \%$ they have never been to University ( 0 year University).

\subsubsection{Household Access to Finance}

According to the findings of the research, majority of the HHs $66 \%$ they have bank accounts with SACCOs, $6 \%$ they have accounts with MFIs and $21 \%$ they have bank accounts with commercial banks On the types of the services, $87.8 \%$ of the households the relate with FSPs for only cash deposit and withdrawal operations, while only $10.6 \%$ have confirmed that they even do request for loans (Table 8).

Table 8: Low income HHs access to $\mathrm{FSPs}^{3}$ \& Types of Services

\begin{tabular}{llccccc} 
& & \multicolumn{5}{c}{ Type of services received } \\
\cline { 3 - 7 } & & Loans & $\begin{array}{c}\text { Deposit \& Money } \\
\text { Withdrawal }\end{array}$ & Others & Total & $\%$ \\
\hline Accessed FSPs & SACCO & 4 & 75 & 2 & 81 & $66 \%$ \\
in Last 12 & MFI & 3 & 4 & 0 & 7 & $6 \%$ \\
Months & Commercial Banks & 3 & 23 & 0 & 26 & $21 \%$ \\
& Others & 3 & 6 & 0 & 9 & $7 \%$ \\
\hline & Total & $\mathbf{1 3}$ & $\mathbf{1 0 8}$ & $\mathbf{2}$ & $\mathbf{1 2 3}$ & $\mathbf{1 0 0}$ \\
\hline
\end{tabular}

Source: Author's field study, 2019

\subsection{Research results on HH Economic Characteristics}

\footnotetext{
${ }^{3}$ FSPs: Financial Service Providers
}

\subsubsection{Access to assets}

White \& Hamm (2014) used an urban agriculture and cityplanning approach to give general incites on urban food insecurity. 
They argued that food access is more of a problem to the less socially connected, with less access to vital resources. Their arguments were in agreement with Frayne et al. (2009) that the socially and structurally less empowered are more vulnerable. Bashir et al. (2012) found Punjab Pakistan households with ownership to land and livestock to be associated with less food insecurity levels. Gambo Boukary et al. (2016) employed the Principal Component Analysis and Structural Modelling Approach on a cross sectional data in Niger and found safety nets and higher asset index to be positively correlated with higher food security.

The study findings show that majority of low income HHs, 76.7\% do not have access to assets like land an houses, $\mathbf{5 \%}$ have confirmed to own houses while $\mathbf{8 \%}$ own land. $\mathbf{1 3 \%}$ of the low incomes HHs who own land and house have confirmed that they use them for business purposes and generate income that they use at $\mathbf{1 0 0 \%}$ for buying food for their families.

Table 9: Assets ownership and usage for income generation

\begin{tabular}{lcccc}
\hline & Owned Assets & \multicolumn{2}{c}{ Used for generating Income } \\
\hline & Frequency & Percent & Frequency & Percent \\
\hline House & 118 & 26.5 & 15 & 3.4 \\
Land & 10 & 2.2 & 24 & 5.4 \\
TV & 8 & 1.8 & 1 & .2 \\
Sofa set & 34 & 7.6 & 1 & .2 \\
Telephone & 90 & 20.2 & 14 & 3.1 \\
Radio & 30 & 6.7 & 2 & .4 \\
Bicycle & 10 & 2.2 & 7 & 1.6 \\
Moto & 1 & .2 & 1 & .2 \\
None & 94 & 21.1 & 231 & 51.9 \\
Other & 10 & 2.2 & 5 & 1.1 \\
Total & 404 & 90.8 & 301 & 67.6 \\
Missing & 41 & 9.2 & 144 & 32.4 \\
\hline Total & $\mathbf{4 4 5}$ & $\mathbf{1 0 0 . 0}$ & $\mathbf{4 4 5}$ & $\mathbf{1 0 0 . 0}$ \\
\hline
\end{tabular}

Source: Author's field study, 2019

The majority of the low-income households $69 \%$ said that they don't own any thing that can serve as security in an emergency situation, only $3.8 \%$ and $2.5 \%$ have confirmed to have some of their assets; houses and land respectively that can serve as insurance in cases of emergencies; and mobile phone gadgets have been said to be relied on as assets that can serve as insurance in the cases of emergency, $7.2 \%$ of households confirmed so (Table 10).

Table 10: Assets that can serve for insurance

\begin{tabular}{lcc}
\hline Asset & Frequency & Percent \\
\hline Bicycle & 5 & 1.1 \\
House & 17 & 3.8 \\
Land & 11 & 2.5 \\
Mobile phone & 32 & 7.2 \\
Motorbike & 1 & .2 \\
Motorcycle & 1 & .2 \\
None & 307 & 69.0 \\
Radio & 10 & 2.2 \\
Sofa set & 13 & 2.9 \\
TV & 10 & 2.2 \\
\hline Total & $\mathbf{4 4 5}$ & $\mathbf{1 0 0 . 0}$ \\
\hline
\end{tabular}

Source: Author's field study, 2019 


\subsubsection{Employment Status of Heads of $\mathbf{H H}$}

The findings of the research reveal that only $39.8 \%$ of the heads of low-income households are employed: $19.4 \%$ do have permanent employment while $80.6 \%$ they do casual work (Table 12). $45.8 \%$ have confirmed that they are self-employed and $30 \%$ that are employed in the private sector. In regards to who employ them; $45.8 \%$ said to be self-employed, $46.4 \%$ are employed by in the private sector while only $6.5 \%$ are employed by government and $1.3 \%$ employed by the civil society.

Table 11: Employers for the Heads of $\mathrm{HH}$

\begin{tabular}{lcc}
\hline Employment status & Frequency & Percent \\
\hline Have a Job & 156 & 39.8 \\
Unemployed & 236 & 60.2 \\
\hline Total & $\mathbf{3 9 2}$ & $\mathbf{1 0 0 . 0}$ \\
\hline
\end{tabular}

Source: Author's field study, 2019

According to UN-HABITAT (2008), when urban growth combined with limited employment opportunities in cities it leads to a more rapid increase in poverty in urban areas than in rural areas. A massive 43 percent of African's urban populations live below the poverty line. In several Sub-Saharan nations that share even exceeds 50 percent and Africa's urban slum populations continue to grow: $69 \%$ of all households in Addis Ababa, $65 \%$ in Dar es Salaam and 50\% in Kampala and Nairobi are slum households.

Table 12: Types of Employments

\begin{tabular}{lll}
\hline Type & Frequency & Percent \\
\hline Casual work & 125 & 80.1 \\
Permanent job & 31 & 19.9 \\
\hline Total & 156 & 100.0 \\
\hline
\end{tabular}

Source: Author's field study, 2019

Table 13: Sector of Employment

\begin{tabular}{lcc}
\hline Profession & Frequency & Percent \\
\hline Agriculture/Agribusiness & 62 & 39.7 \\
Plumber & 2 & 1.3 \\
Masson & 18 & 11.5 \\
Carpenter & 1 & .6 \\
Teacher & 1 & .6 \\
Other & 72 & 46.2 \\
\hline Total & 156 & 100.0 \\
\hline
\end{tabular}

Source: Author's field study, 2019

According to the research, the majority $89.7 \%$ of lowincome households they earn daily wages and only $10.3 \%$ earn monthly salaries, only $29.5 \%$ they have confirmed that their salaries/wages are regular while $70.5 \%$ said that it is irregular (Table 14). Apart from the listed skilled employments categories that were given as options for respondents, from the survey it was observed that the majority of respondents said that they are employed in the category of "Other types" of employments. The provided details show that other occupations that heads of households are involved in cut across all various informal and nonskilled categories of employment in City of Kigali; they mentioned street vendors and other informal businesses which occupy $4.9 \%$, those involved in man power category are $2.7 \%$, cleaners are $1.3 \%$, aid-masons are $1.3 \%$ and those involved in security employments are $1.1 \%$. 
Table 14: Type of Remunerations

\begin{tabular}{lccccc}
\hline \multicolumn{3}{c}{ Type of remuneration } & \multicolumn{3}{c}{ Regularity } \\
\hline Received & Frequency & Percent & Regular & Frequency & Percent \\
Daily & 140 & 89.7 & No & 110 & 70.5 \\
Monthly & 16 & 10.3 & Yes & 46 & 29.5 \\
\hline Total & $\mathbf{1 5 6}$ & $\mathbf{1 0 0 . 0}$ & & $\mathbf{1 5 6}$ & $\mathbf{1 0 0 . 0}$ \\
\hline
\end{tabular}

Source: Author's field study, 2019

\subsubsection{Household Access to Finance}

According to the findings of the research, majority of the HHs $66 \%$ they have bank accounts with SACCOs, $6 \%$ they have accounts with MFIs and $21 \%$ they have bank accounts with commercial banks On the types of the services, $87.8 \%$ of the households the relate with FSPs for only cash deposit and withdrawal operations, while only $10.6 \%$ have confirmed that they even do request for loans (Table 15).

Table 15: Low income HHs access to $\mathrm{FSPs}^{4} \&$ Types of Services

\begin{tabular}{llccccc} 
& & \multicolumn{5}{c}{ Type of services received } \\
\cline { 3 - 7 } & & Loans & $\begin{array}{c}\text { Deposit \& Money } \\
\text { Withdrawal }\end{array}$ & Others & Total & $\%$ \\
\hline Accessed FSPs & SACCO & 4 & 75 & 2 & 81 & $66 \%$ \\
in Last 12 & MFI & 3 & 4 & 0 & 7 & $6 \%$ \\
Months & Commercial Banks & 3 & 23 & 0 & 26 & $21 \%$ \\
& Others & 3 & 6 & 0 & 9 & $7 \%$ \\
\hline & Total & $\mathbf{1 3}$ & $\mathbf{1 0 8}$ & $\mathbf{2}$ & $\mathbf{1 2 3}$ & $\mathbf{1 0 0}$ \\
\hline
\end{tabular}

Source: Author’s field study, 2019

\subsection{Descriptive Analysis on Effect of Inflation on Food Security}

According to Granville and Mallick (2006), when the nominal wages on which low earners depend stagnate or grow at a lower rate than prices, inflation can depress workers' real income and generate poverty. This will also be more likely the more the prices of basic goods are affected. On the other hand, the oftencited "inflation tax" reducing the purchasing power of monetary assets may not affect those already below the poverty line, since these individuals hold few liquid balances to begin with.

In urban areas, higher food prices may substantially hurt the poor because, typically, little food is produced in such areas and because food typically accounts for a large share of expenditures for the poor. In order to cope with the reduction in disposable income resulting from higher food prices, households will engage in new economic activities, sell assets or borrow in order to mitigate the decline in consumption. They also commonly reduce expenditures on health and education and shift dietary patterns towards cheaper (starchy) foods and away from micronutrient-rich foods such as milk, meat, and fruits and vegetables (FAO, 2009). The findings of the research reveal that majority $95.4 \%$ of low income $\mathrm{HHs}$ adjust to raise in markets prices by cutting down household's expenses including food and this meaning reducing quality and quantity of the food consumed by household members, in other words compromising food security for the households member. Only $32.1 \%$ of the households look for alternatives to keep the quality \& quantity of food consumed at household.

\footnotetext{
${ }^{4}$ FSPs: Financial Service Providers
} 
Table 16: HHs adjusting to the rise in prices and rent by cutting down HHs expenses including food and relocating to cheap houses

\begin{tabular}{lcccc}
\cline { 2 - 5 } & $\begin{array}{l}\text { HHs adjusting to the rise in } \\
\text { prices by cutting down HHs } \\
\text { expenses including food }\end{array}$ & $\begin{array}{l}\text { HHs moving to cheaper houses } \\
\text { adjusting to the raise of rent }\end{array}$ \\
\hline Sometimes & Frequency & Percent & Frequency & Percent \\
Rarely & 133 & 34.1 & 47 & 19.9 \\
Frequently & 177 & 15.9 & 21 & 8.9 \\
Never & 18 & 45.4 & 93 & 39.4 \\
Total & $\mathbf{3 9 0}$ & $\mathbf{1 0 0 . 0}$ & $\mathbf{2 3 6}$ & $\mathbf{1 0 0 . 0}$ \\
\hline
\end{tabular}

Source: Author's field study, 2019

Majority of low income households, $75 \%$ said they do never borrow money from friends to cater for feeding families when the prices go up, the majority $\mathbf{9 5 \%}$ said also they never borrow from the Financial Service Providers (FSPs) to cater for food when prices go up, and $\mathbf{8 5 \%}$ said they never borrow from saving groups.

According to table 8 above, majority (68.2\%) of the lowincome households in City of Kigali, they opt moving looking for cheaper houses as a strategy of dealing with the increase in rent which means in other words that low-income households attribute less priority to quality of houses they stay in. This also explains the mobility of this category of City inhabitants from the deep city location towards the city outskirts developed as the city expands.

\subsection{Regression Results for determinants of Households Food Expenditure}

The research aimed to study among other objectives how HH's economic characteristics influence households' food security for the low-income households in City of Kigali. The studied factors include; i) Household owned assets (Land, shelter), ii) Employment/occupation status of the head of the household (Employed: full time, part time, casual labor, Unemployed, doing skilled labor or non-skilled labor) and iii) Household access to financial services (loans).

According to the research findings from the multiple linear regression model, it is observed that there is no statistical significance for the three economic variables; Household Owned Assets, Employment of the Head of Household and Household Access to Finance and food security for the low- income households in City of Kigali.

Table 17: Regression of the Social Factors with HH food Expenditure 


\begin{tabular}{lcccc}
\hline \multicolumn{4}{c}{ (A) Model Summary } \\
\hline Model & $\mathrm{R}$ & R Square & Adjusted R Square & Std. Error of the Estimate \\
1 & $.397^{\mathrm{a}}$ & .158 & -.264 & .43848 \\
a. Predictors: (Constant), (1) HH_Asset /House, (2) HH_Access_Fin & \\
b. Dependent Variable: HH Food Expenditure & \\
\hline
\end{tabular}

(B) ANOVA

\begin{tabular}{llccccc}
\hline Model & & Sum of Squares & df & Mean Square & F & Sig. \\
1 & Regression & .144 & 2 & .072 & .374 & $.710^{\mathrm{b}}$ \\
& Residual & .769 & 4 & .192 & & \\
Total & .913 & 6 & & &
\end{tabular}

a. Dependent Variable: HH Food Expenditure

b. Predictors: (Constant), (1) HH_Asset/House, (2) HH_Access_Fin

(C) Coefficients

\begin{tabular}{|c|c|c|c|c|c|c|c|c|}
\hline & & \multicolumn{2}{|c|}{$\begin{array}{c}\text { Unstandardized } \\
\text { Coefficients }\end{array}$} & \multirow{3}{*}{$\begin{array}{c}\text { Standardized } \\
\text { Coefficients } \\
\text { Beta }\end{array}$} & \multirow{3}{*}{$\underset{2.593}{t}$} & \multirow{3}{*}{$\begin{array}{l}\text { Sig. } \\
.061\end{array}$} & \multicolumn{2}{|c|}{$\begin{array}{c}\text { Collinearity } \\
\text { Statistics }\end{array}$} \\
\hline \multicolumn{2}{|c|}{ Model } & B & Std. Error & & & & Tolerance & VIF \\
\hline 1 & (Constant) & 7.779 & 3.000 & & & & & \\
\hline & HH_Access_Fin & .182 & .232 & .395 & .786 & .476 & .835 & 1.198 \\
\hline & HH_Asset /House & .238 & .367 & .326 & .649 & .552 & .835 & 1.198 \\
\hline & endent Variable: HH & Food Ex & diture & & & & & \\
\hline
\end{tabular}

\section{Source: Author's field study, 201}

\section{CONCLUSION AND RECOMMENDATIONS}

This section is aimed at giving conclusion and recommendations on the major findings of this study; it gives in a summarized manner the research findings in regards with the research and conclusions on study hypotheses. This section includes also recommendations on how best to address issue of food security in the low-income households in City of Kigali, Rwanda and provide indication on issues for further investigation. The study has revealed that economic factors; access to asset (Land and House), Access to finance from the formal financial institutions (Bank, MFIs and SACCOs), the level of education for the head of households do not significance influences on lowincome households food security in City of Kigali as per results from the linear regression model.

\subsection{Summary of Key Findings}

The overall objective of this study was to determine how the socio-economic and demographic determinants affect household's food expenditure for the low-income households in City of Kigali. In particular, the specific objective covered under this paper is to analyze how HH's economic characteristics influence households' food security for the low-income households in City of Kigali. The study collected data through a survey; data were analyzed and presented, for this paper specific attention is given to the objective mentioned above of studying how HH's economic characteristics determine the level of food security in low income HHs in City of Kigali. Theoretical and empirical literatures were used to compare the results of the study with previous studies.

As the objective of the study sought to investigate how HH's Economic Characteristics influences food security for the low income households in City of Kigali with focus on three key factors; i) Household owned assets (Land, shelter), ii) Employment/occupation status of the head of the household (Employed: full time, part time, casual labor, Unemployed, doing skilled labor or non-skilled labor) and iii) Household access to financial services (loans), influence livelihoods for the lowincome households in City of Kigali

The results from both Multiple Linear Regression model have revealed that there is no statistical significance for the three economic variables; Household Owned Assets, Employment of the Head of Household and Household Access to Finance as predictors of household food security. We therefore, fail to reject $\mathbf{H}_{0}$, which says that HH's economic characteristics do not influence the food security for the low-income households in City of Kigali.

\subsection{Recommendations}

The situation of economic capacity and Food security and of the low-income households in City of Kigali can be addressed for a better and more improvement livelihoods. The most important factor to be addressed is the economic capabilities through the social economic empowerment of the low-income 
households and also increasing food accessibility for the lowincome earners within the city of Kigali.

\subsubsection{Social-Economic Empowerment for improved livelihood}

The research results have revealed a low level of engagement of the low-income households in income generating activities within the City of Kigali, which normally should be one of the key sources of income for this segment of population. Looking at the factor that the majority of heads of households belongs to the working age range, this can allow for long term socio-economic behavioral transformational and support programs.

The City of Kigali should invest more effort to improve entrepreneurship and financial literacy among the low-income households, which will increase the skills of the low-income category (Ubudehe $1 \& 2$ Categories) and help them to improve their level of engagement into income generating activities, join the formal sector from the inform and increase their level of working with financial services providers as it was observed as an issue from the research results.

Depending on the City priority areas and competitive advantages; the City of Kigali should attract or initiate more programs that target for social -economic empowerment for the poor people within the City with an assumption that currently, fewer of the development partners put their focus and interventions in City of Kigali to benefit the low-income population. The low income/poor people within the cities tend to be forgotten in most programs targeting to improve livelihood of the poor yet they are more disadvantaged compared to the other poor persons in rural areas.

\subsubsection{Explore potentials for Urban Agriculture}

With the aim for jobs creation and improving food security for the poor families within the City of Kigali, the urban agriculture should be given much more priorities and be explored as a sector that can trigger the creation of employments and generate on and off farm businesses for a big number of City inhabitants especially the poor people.

FAO defines urban agriculture as the growing of crops, vegetables, fruits and livestock keeping as well as non-food products (Orsini et al., 2013). Maxwell et al. (1998) argued that urban agriculture increases household food and nutrition. Other scholars have explained how urban agriculture enhances livelihoods of the urban poor. For example, asserts that urban agriculture brings additional income.

According to NISR (2016), in total, 74 percent of Rwandan households practice agriculture, including $88 \%$ of rural households and $34 \%$ of urban households among households practicing agriculture. Based on the study findings, the study recommends that the City of Kigali give much more priority to urban agricultural practices, it is important that the City acknowledges the situation of the low-income households within the City and through Ministry of Agriculture formulates policies that govern and promote urban agricultural practices.

Also, the City of Kigali in collaboration with the Ministry of Agriculture together with Rwanda Cooperative Agency, should be at the fore front in empowering and organizing the city lowincome households in strong cooperatives to benefit and turn into economically viable the available non exploited swamps in the suburbs of the City of Kigali.

\subsection{Areas for further research}

- The low involvement of City of Kigali low-income household in income generating activities requires further studies to understand the reasons behind for further recommendations;

- There is a need for further researches in the area of Urban and Peri-Urban Agriculture development in City of Kigali;

- There is a need to investigate further the phenomenon and impact of low-income households' mobility searching for affordable shelters within the City of Kigali.

\section{REFERENCES}

[1] Adejobi A.O.(2004) Rural poverty, Food Production and Demand in kebbi state Nigeria, unpolished $\mathrm{PhD}$ thesis, department agricultural economics, university Ibadan.

[2] Becquey, E., Martin-Prevel, Y., Traissac, P., Dembélé, B., Bambara, A. and Delpeuch, F. (2010). The Household Food Insecurity Access Scale and an Index-Member Dietary Diversity Score Contribute Valid and Complementary Information on Household Food Insecurity in an Urban West-African Setting. Journal of Nutrition 140: 12 2233-2240

[3] Bickel et al, 2000. Guide to Measuring Household Food Security, USDA's Washington;

[4] Bouis, H. E., and L. Haddad. 1990. Effects of agricultural commercialization on land tenure, household resource allocation, and nutrition in the Philippines. Research Report 79. Washington, D.C.: International Food Policy Re- search Institute.

[5] Coates, J., Swindale, A. \& Bilinsky, P. (2007). Household Food Insecurity Access Scale (HFIAS) for Measure of Household Food Access: Indicators Guide (Vol. 3).

[6] de Zeeuw, H., \& Prain, G. (2011). Effects of the global financial crisis and food price hikes of 2007/2008 on the food security of poor urban households. Urban Agriculture Magazine, 25, 36-38.

[7] Dhar Chakrabarti, P.G. (2001) 'Delhi's ongoing debate on informal settlements and work places: Issues of environmental jurisprudence.' Paper presented to the Network-Association of European Researchers on Urbanisation in the South (N-AERUS) and European Science Foundation (ESF) International workshop on Coping with informality and illegality in human settlements in developing cities. Leuven and Brussels 23-6 May 2001.

[8] Dixon, J., Omwega, A., Friel, S., Burns, C., Donati, K., \& Carlisle, R. (2007) The health equity dimensions of urban food systems. Journal of Urban Health, 84(1), 118-129.

[9] Dyson, T. Population and Food, Global Trends and Future Prospects. London: Routledge, 1996

[10] FAO, Challenges of food and nutrition security, agriculture and ecosystem management in an urbanizing world, 2010.

[11] FAO. 2009. The State of Food Insecurity in the World 2009. Economic crises istepimpacts and lessons learned. Rome.

[12] Food and Agriculture Organization, the place of urban and peri-urban agriculture in national Food security programmes, 2011.

[13] Government of Rwanda, Rwanda Natural Resources Authority, Rwanda Supply Master Plan for fuel and charcoal, July 2013.

[14] Kundu, A. and N. Sarangi 2007 Migration, employment status and poverty: an analysis across urban centres. Economic and Political Weekly, 42 (4): 299-306.

[15] Lester R. Brown, Mobilizing to Save Civilization, Earth Policy Institute, New York 2008.

[16] Maxwell, D., Ahiadeke, C., Levin, C., Armar-Klemesu, M., Zakariah, S., Lamptey, G.M., 1999. "Alternative Food Security Indicators: Revisiting the Frequency and Severity of 'Coping Strategies."” Food Policy. Vol. 24 (4), pp. 411-429. 
[17] Maxwell, S. 1996. "Food Security: A Post-modern Perspective". Food Policy, Vol.21, No 2, pp. 155-170

[18] Mougeot, Luc J.A. Ed. , 2005. AGROPOLIS. The Social, Political and Environmental Dimensions of Urban Agriculture. Earthscan. London.

[19] National Institute of Statistics of Rwanda (NISR), Rwanda 2015/Comprehensive Food Security and Vulnerability Analysis, April-May 2015.

[20] National Institute of Statistics of Rwanda (NISR), Rwanda Poverty Profile Report, 2013/14, August 2015. Kigali.

[21] National Institute of Statistics Rwanda and the Ministry of Finance and Economic Planning. 2015. Rwanda Population and Housing Census 2015. Kigali.

[22] Ravallion, Martin. 2007. Urban poverty. Finance and Development 44 (3);

[23] S. Bhalotra, and M. Umaña-Aponte. 2009. Distress work amongst women? Micro data evidence from 66 developing countries on women's work participation as an insurance device. Bristol, UK, Department of Economics, University of Bristol

[24] Shapouri, S., Rosen, S., Peters, M., Tandon, S., Gale, F., Mancino, L. and Bai J., 2011. International Food Security Assessment, 2011-2021. USDA Economic Research Service, July 2011.

[25] Thomas Vinod, The measurement of spatial differences in poverty: the case of Peru, World Bank Staff Working Paper 273, 1978.

[26] UN-HABITAT (2008), The state of African cities 2008, a framework for addressing urban challenges in Africa, Nairobi, Kenya is:

[27] UN-HABITAT, 2010. State of the World's Cities 2010/2011: Bridging the Urban Divide. London and Sterling, VA: Earthscan. SEEP?

[28] UN-HABITAT. 2006. State of the World's Cities 2006/7.The Millennium Development Goals and Urban Sustainability: 30 Years of Shaping the Habitat Agenda. London: Earthscan for UN-Habitat;
[29] UNEP, The environmental food crisis - The environment's role in averting future food crises, February 2009;

[30] United Nations Children's Fund, Situation Analysis of Children in Rwanda, Rwanda 2018.

[31] United Nations Economic Commission for Europe, Canaberra Group Handbook on household Income statistics, 2nd Ed, Geneva 2011.

[32] Vincent Manirakiza, Promoting inclusive approaches to address urbanization challenges in Kigali, 2014.

[33] Webb, P., Coates, J., Frongillo, E.A., Rogers, B.L., Swindale, A. and Bilinsky, P., 2006. Measuring household food insecurity: Why it's so important and yet so difficult to do. Journal of Nutrition 136: 1404S-1408S.

[34] World Bank, RUAF Foundation, EU. 2010. The Growth of Cities in East Africa: Consequences for Food Supply.

\section{AUTHORS}

First Author - Emmanuel NZEYIMANA, PhD Candidate, Jomo Kenyatta University of Agriculture and Technology, Development Studies, E-Mail: emmavld@yahoo.fr And emmavlady@gmail.com, Tel: +250 788384114

Second Author - Prof. Maurice M. SAKWA (PhD), Jomo Kenyatta University of Agriculture and Technology

Email: msakwa@jkuat.ac.ke

Third Author - Prof. Gregory NAMUSONGE (PhD), Jomo

Kenyatta University of Agriculture and Technology

Email: gnamusonge@jkuat.ac.ke 